JournEEL

E-ISSN: - Vol. 1 No. 1, June 2019, Page. 11-30

\title{
Improving the Students' Creativity in Writing Descriptive Texts by Using Super PC Media
}

\author{
Lailatul Musyarofah \\ STKIP PGRI Sidoarjo, Email: ibulaila7810@ gmail.com \\ Amaliah \\ STKIP PGRI Sidoarjo, Email: amaliahnikita@gmail.com
}

\begin{abstract}
The purpose of this study was to describe the increase of students' creativity in writing descriptive text by using Super PC with mind map method. The result of this study wasthe students' creativity could be developed by means of creative teachers who also contextualized learning with media that students have known every day, that is by using super PC (Supermarket Product Catalog) media. The use of Super PC media in the seventh grade of Junior High School 2 Sidoarjo brings a positive impact to the students' creativity in writing descriptive text. This can be seen from the comparison of Cycle I, that is, with index 2.26, with less creative category. Whereas in the second cycle (Cycle II), the index was improving to 4.45 with a very creative category. Students have a creative character and in terms of practicality, clarity, quality and usefulness. The results of writing gradually improve positively. This media is also specifically designed to overcome saturation, limited vocabulary in using international language in the implementation of learning that prepares students in the 21st century, especially students' creativity in writing descriptive text.
\end{abstract}

Keywords: Writing, Creativity, Super PC.

\section{INTRODUCTION}

The role of the language now is very necessary so that young generation becomes a generation that can be relied on communicatively in the 21 st century. Mastery of languages is a priority. Mangunwijaya (2003: 186) believes that in this age of communication, technology, information, mastery of international languages is more important than mathematics, for example, or more precisely: mathematics is a form of specialist language, while other tangible languages are appropriate for daily communication day, insight and taste, if students want to survive, advance, become whole human beings.

However, the students'creativity primarily in writing English texts becomes a great challenge for teachers, since there is a great invention of technology where people can open wide sources on the internet and copy the writing there easily. The implementation of writing learning process really requires hard work, considering this 
lesson as a foreign language. The most common case, students often make the same dialogue with other friends or just take from internet sources. This problem is caused by many factors, including (1) limited mastery of English vocabulary, (2) differences in language structure of Indonesian and English, for example students use the Indonesian language mindset compilation to make English sentences, (3) lack of teacher's creativity preferences in using learning media, and (4) students' learning motivation with a low sense of other smarter friends.

For this reason, in the learning process, of course the teacher must understand the creative way so students can be more creative in creating them into products, especially transactional texts. This creative character is an identity, consisting of thoughts that must be visible to students, developed and cultivated by the teacher. This character value needs to be developed and implemented in the school curriculum, and poured into the syllabus and the subject matter in the lesson plan and its implementation.

Because of it, the author begins to think about creating creative media so that students get an interesting learning experiences, enabling them to have creative characters and produce English texts that contain novelty. Various innovations and creativity must be continuously carried out by the teacher in designing and implementing learning. The learning design preparation in question is looking for alternative strategies, tools and media that are optimal in helping individual students master the learning material which eventually reaches the learning objectives or competencies.

Media is one aspect of learning design that enables innovation. This is one of the teacher's tasks, namely to choose effective and efficient learning media. Why is the media needed in the learning process? The learning process is generally the same as the process of communication or information, namely the process of transferring messages from a source, using channels, to the recipient, with the aim of attracting results or results. In the learning process, information consists of material, the source is the teacher, the channel consists of the media and the recipient is the student produced / the result of increasing knowledge and skills.

The teaching and learning process is designed by the principles of teaching and learning by designing activities that enable students to make meaning or understand. 
Learning is responsible for their own learning, learning success is very important by their active learning, but the teacher is still responsible for developing motivation that encourages and is responsible for students for lifelong learning, for it to suit the purpose of learning. Teachers must able to develop the potential needed by students.

Ideally in learning, the teacher provides real and direct experience to students but because of participation factors this cannot be done. Therefore, media is needed. Media innovation is very urgent and important as the development of science and information technology. It provides a real experience in students in the learning process. This learning innovation is directed at contextual learning where students actually have a relationship with the visual media presented. Visual mediawhich is taken from real pictures of product catalogs provide a sense of "close" to students, because they can get these product catalog in their daily lives.

This "close" feeling at the initial stage will attract student's attention and then with the teacher's direction of course, it can attractstudents'curiosity. If they have already enjoyed learning, the process of transferring information will be easier because their thoughts have been opened. With that kind of process, creative character will ask them to create sentences and then paragraph. In this work, the author uses Media Super PC which stands for Supermarket Product Catalog, namely media in the form of product images taken from supermarket product catalogs, as a form of creativity and innovation to enhance students' creativity, especially in writing skill of descriptive text.

\section{Character Education}

Realizing that education is a package of formation and thought, Ki Hadjar Dewantara, who believed in the ability of thought and feeling for the sake of the nation with cultural style, had conditioned Indonesia's education to be cultured long ago. Character education is like an activity of carving, giving a touch that will make it have more value.Lickona (2015: 81) argues that we are processing in our character, from a value to a disposition in good responsibility. That is why both being intelligent and having good character must be mastered and must become a main part of school education.

Hidayat and Ramdhan (2016: 33-34) mention four types of character education that are inspired by the principles of Pancasila, namely: 
1) Character that comes from the heart (piety, honesty, gratitude, patience, orderly, etc.)

2) Character that comes from thinking (creative, innovative, analytical, intelligent, curious)

3) Sports / kinesthetic characters (healthy, resilient, persistent, sportsmanship, etc.)

4) Character originating from a sense of intention (humanity, mutual cooperation, nationalism, etc.)

From the four types of characters above, researcher focuses on the second character, characters from thinking, in the form of creative characters that are very important for today's young generation.

\section{Creativity}

Sternberg \& Lubart in Aziz (2009: 117) mentions the following characteristics of creative character: (1) perseverance in the face of challenges (2) the courage to take risks (3) the desire to develop (4) tolerance (5) open minded to new experiences (6) determination. While the criteria for creative writing are based on three creative product categories, namely novelty, resolution (resolution) and form (style).

Jason Theodore who promotes creativity as an act of relating different things to one new thing in an unapproved way. Aris Ananda, (2014: 48) an expert in the field of creativity, who is also a designer, consultant, writer, coach, speaker, reformulates the Theodore's resolution on creativity:

a) Action

Action is a follow-up action or realization of a basic idea. Can people be rich just by saving money or idea that is in a drawer and waiting to be bought by someone? The idea must be executed, realized, followed up, this is called as number one requirement, action. From this action, Ananda (2014: 52-54) raises various questions about the challenges of being creative: (1) do you have trouble starting?; (2) are you reluctant to experiment? (3) Do you have trouble completing work? (4) do you like asking?

\section{b) Connection}

Connection is a relationship that consists of two things, the first is the relationship between ideas and the second is the relation of ideas to the audience. Creativity without connection is not creativity at all. Ananda (2014: 63-65) raises 
questions to ask for this connection side assistance: (1) Are you very interested in the results of the research? (2) Do you have curiosity about how the system works? (3) Do you patiently hear other people's ideas? (4) Are you comfortable considering the culture of others?

c) Deviation

Deviation is a different perspective from common people. Ananda (2014: 131) argues about how to make a different perspective. They are glasses and eyes. Blindfolds are relaxed, hanging out withcreative ideas at certain times. While the glasses consist of a combination, adaptation, modification, fitting in other uses, remodeling, changing grooves, elimination or minimization, artificial displacement. From the Ananda deviation element (2014: 67-69) raises questions (2) Do you avoid new things? (3) Is it difficult to find ideas that are truly new? (4) Is it difficult to imagine a new perspective?

These three-element questions are the questions that the author uses for measuring instrument for student creativity, consisted of questionnaires for students and questionnaire for teachers and observation sheets regarding the creative character of students.

\section{Writing skills}

Richards and Renandya (2002: 319-320) explains about the procedure of implementing writing process. They are: (1) modelling, (2) process and product relation, (3) skill practice (making draft, composing, revising, editing), (4) providing the varied students' need. In this research the teacher designs the process of writing to improve students' creativity. Students make groups and in each group one picture is given. For example, media of picture can be used to ask questions for brainstorming. Then, teacher provides information about things that explain the physical characteristics of objects. The process of writing drafts will be helped by the presence of images that can be seen visually.

Seow (2002: 204) proposes the four stages of process writing. They are planning, drafting, revising, and editing. Planning and drafting are the stages when process activated, revising and editing are the process terminated. Planning (prewriting) stimulates students thought. Teachers can stimulate their students by 
brainstorming, clustering, rapid free writing, or generating $\mathrm{WH}-$ questions about a topic.(Seow, 2002: 216).

Then students make drafts, after that the teacher responds by giving specific suggestion, so that the students can revise based on the feedback of the teacher. Editing is tidying up their texts (grammar, spelling, diction, structure, and accuracy).Ferris (2002: 329-333) explains the three steps to become self-sufficient editors. They are focusing on form, recognizing major error types, and self-editing practice. Brown (2002: 357) explains six categories for evaluating writing. They are: (1) content, (2) organization, (3) discourse, (4) syntax, (5) vocabulary, and (6) mechanics.

\section{Media of Learning}

Sudjana \& Rivai (2015: 1), two media experts exlplain there are six kinds of learning media: projection media, audio, graphics, photography, environment and three dimensions. Graphic media can be images, comics, posters, cartoons, diagrams or graphs or charts. The author chose graph media because it is the most practical to choose. Graphic media, in the form of images in this paper are SuperPC (= Supermarket Product Catalog). It is clearly cheap. In the implementation, it is easy for teachers to make, to carry, and easily move around.

Learning media must be useful, teachers should pay attention to important things about the learning they use, as revealed by Sudjana \& Rivai (2015: 6) that when the attention of students is reduced, because of boredom and unattractive teachers, learning resources, difficult to find materials the benefits.

The students' enthusiasm will direct them to give mentally-focused attention to an object where it plays an important role in the success of learning. However, attention has a difficult nature to maintain for a long time. Attention will remain for a while changing. Therefore, besides the media that needs to be done, attention control techniques such as movement, change, shock, tension, funny, and so on.

So there are two keywords in attracting students' enthusiasm that illustrates interesting media and techniques. The creativity is neededand use media. In the case of media, media images that can be used must be contextual and up-to-date because this will make students believe "close" to the object being studied. 


\section{Super PC media}

This Super PC media is the original creation of researchers to develop the creative character of students. According to the meaning Super is a supermarket, PC stands for Product Catalog. It is a contextual image, involving in everyday matters of students, attracting students to be interested in class activities.King (2017:1) states that lessons involving higher order thinking skills require particular clarity of communication to reduce ambiguity and confusion and improve student attitudes about thinking tasks. This media is able to reduce ambiguity and confusion to make students think.

The term catalog itself comes from the Greek phrase Katalogos. It has a meaning 'obey', while logos have various meanings such as words, structure, reason and reason. In particular the catalog is interpreted as an arrangement or list of goods or objects arranged in a certain order with a specific purpose. Which is issued by PC (Product Catalog) here is a list of items or objects arranged in a certain order that are issued as promotional media by supermarkets. Every supermarket must order their product catalog.

However, catalogs can vary according to the same demands, for example Carrefour Supermarket uses the term "Price and Promo Catalog", and Hypermart Supermarket uses the term "Shopping Catalog and Promotion." "Super" reviews at supermarkets, or supermarkets that sell their products independently such as Indomart, Alfamart, Hypermart, Carefour, etc., then the word "PC" means Product Catalog. More details, "Products" on the objects sold, and the word "Catalog" in the sense of "list", Based on the explanation above, the term "Super PC" in this paper has a list of products sold by supermarkets.

In this paper, the media images used are easy-to-find and free self-service product catalogs. Pieces of product images are usually equipped with prices and other writings such as discounts, product excellence, maximum purchases and so on. The image of the product is cut one by one and then affixed to cardboard so that it is made like a kind of flash card. The teacher can use the product image as a medium in learning skills such as Reading (Reading), Writing (Writing), Listening (listening), and Speaking (speaking) as well as learning material or themes such as descriptive, narrative, procedure, telling, functional text and so on. But in this research, the writer focuses on 
students writing skill. This Super PC media is very practical, simple and easy to make but has many benefits.

\section{RESEARCH METHOD}

\section{Research Design}

In this study, the data to be collected in the study is descriptive, namely the descriptions of student learning activities and this study used a qualitative approach with the type of class action research. Koshy (2005:9) explains that a class action research is a continuous learning process in which the researcher learns and also shares the newly generated knowledge with those who may benefit from it. This research method follows class action research procedure consisting of planning, actions, observation, and reflection.

This research was conducted for about three months. The data collected in this study was about the creativity of students seen from the writing at the initial meeting and information about the result of students writing from teaching experience so far. Furthermore, the results of the pre-test were compared with the achievement of daily test scores in the first and second cycle.

The instruments used in this research are observation Sheet for creativity, Student creativity questionnaire, Lesson Plans and Evaluation rubric. This research uses documentation techniques from students' learning outcomes in two cycles, even semester.

\section{Research Setting}

This research was conducted for about three months since February the seventeenth (preparation phase) up to April the seventh (completing report phase), in the seventh grade (class X) of SMPN 2 Sidoarjo, in the even semester 2016/2017, 35 students (17 males 18 females) with the condition of varied learning styles:

\footnotetext{
$\checkmark$ visual : $51 \%$ (18 students);

$\checkmark$ auditory :29\% (10 students);

$\checkmark$ kinesthetic 20\% (7 students)
} 


\section{Research Procedures}

\section{First Cycle}

\section{Planning}

In the planning stage, the author identifies some of the difficulties encountered at schoolin learning English.Then some problem items were recorded and identified problems related to the learning model and analyzed what could have been done to prepare for the corrective actions. In this phase it is also carried out the preparation of lessonplan and chose the learning model as an alternative to solve existing problems.

\section{Implementation}

At the action stage, the teacher carries out a learning scenario that will be implemented. At this stage the teacher applies the learning model that has been arranged. The teacher will carry out the learning according to the learning plan and carry out the learning process by applying the syntax in the learning that has been prepared. At this stage the observer carries out the actions that have been formulated in the lesson plan in the actual situation. The learning process on the first cycle is conducted with the steps: (1) students write at least 10 English words related to the image, for example, an image of Milk product. Students write words such as white, pure, healthy, drinkable, liquid, powder, sweet, baby, box, cow, glass, spoon, grow and so on, (2) students make sentences from each of these words,(3) teacher help students provide examples or correct students' work, (4) arranging the text from the sentences, (5) each group presents the writing result.

Using this procedure, students unconsciously support brainstorming and creative thinking outside the box (by combining 10 words related to images), learning to string words into sentences, and learning to compose sentences into a good composition. Characteristically, this model supports increasing character by working together, to produce original text.

\section{Observation}

At the observation phase, the teacher prepares and carries out observations of actions carried out continuously. This observation will be done in addition to observing all the actions taken by the teacher for the sake of research, observation is also directed to other interests, namely the response shown by students to the learning model applied to learning. The teacher also made intensive observations based on the agreed 
observation sheet. To facilitate observation, an observation instrument will be prepared for the actions taken as well as an observation instrument for the response shown by students.

In the first cycle, when students write the special characteristics they usually buy, it can be seen that students write in English and Indonesian, they donot seem to understand the request. Then, when the teacher is explaining, most students listen, but some students in the corner are less busy, because they are busy with the group.Students explain to each other about the teacher's request, students who do not understand prefer to ask their friends with Indonesian expression. Some groups seem to find easily ten words related to the picture given, but some groups only write six or seven words.

\section{Reflection}

At the last stage, reflection, the teacher determines the level of success in improving the actions taken and subsequent corrective steps so that they can meet the research objectives. The reflection stage is done after the teacher takes action in the classroom and observes the actions taken. From this reflection it is expected that the team can analyze weaknesses in the implementation or application of learning and certain cases that occur in writing class.

\section{b. Second Cycle}

\section{1) Planning}

In the planning stage, the observer with the writer think to make use a mind map as a technique to make the students' thought and ideasdevelop into more detailed description. Then, the lesson plan is arranged and discuss for further improvement. The media is also prepared to improve students writing creativity.

\section{2) Implementation of Action}

In the second cycle the learning process is conducted (1) students stick the image of super PC in the middle of the paper, (2) students make mind map and develop it into several characteristics of thing description, such asshape, color, made of, price. Students writerelated words such big, round, for shape, green, tallow, blue, colorful for color, and plastic, iron, for material it is made of, expensive, cheap, reasonable for price, and so on, (3) students make sentences from each of these words,(4) teacher help 
students provide examples or correct students' work, (4) students arrange the text from the sentences, (5) each group presents the result of their group work.

\section{Observation}

The focus of observation will be emphasized on the activities of students and also the application of the learning model that is carried out as a scenario for the improvement of the learning process. At this stage, what observers have to do is; observe the behavior of students in participating, monitor the discussion activities between students in the group, follow the understanding of each student towards the mastery of the learning material that has been designed.

\section{Reflection}

Weaknesses in learning sought alternative solutions to improve the quality of the learning process that became the focus of the study. Thus activities are carried out repeatedly until what is expected, so that the problems faced by students can be answered.

\section{The Data Collection Procedure}

To find out the improvement of creativity on students' writing in cycles I and II, the following formula is used:

The students'creativity is using the following formulation:

$\mathrm{C}=\quad$ acquisition score $\times 100$

maximum score

The creativity value of students in one cycle is obtained from both teacher/ observer and students. The score from observer is added with the score from students' average, then divided into two. The average score in cycle $\mathrm{I}$ is compared with cycle II. Students'creativity in this study is expected to obtain 3.5 to 4.49 interested and 4.50 to 5 with very creative qualification. To determine the class' average the formulation is:

$\mathrm{CA}=\underline{\text { Total Value of Students }}$

Number of students

The class average expected in this study is 77

\section{Data Analysis}

There are two important things that need to be considered in the qualitative data analysis, meaning and interpretation. This analysis was carried out since the researchers applied the field. So the compilation of researchers already exists in the field and data 
has been collected, so the compilation has also been analyzed. This action must be carried out continuously, from the beginning to the end of the data collection activity, and carried out repeatedly until there is no new information.

Data on interpretation and meaning will develop and change according to developments and changes in data found in the field. The accuracy of interpretation and analysis depends on the accuracy of the analysis, not on statistical calculations. In data analysis, a judgemnet from the researcher is needed. For this reason, uncertainty bias and subjectivity must be avoided by reviewing, asking collaborators, looking for similar data. Interpretation of content in a systemic and systematic system. Data analysis here applies an interactive model through stages: a) data collection, b) data reduction, c) data presentation, and d) conclusions. To determine individual completeness:

$\mathrm{IC}=\underline{\text { The value achieved by students }} \times 100 \%$ Maximum value

In calculating classical completeness:

\section{$\mathrm{CC}=\underline{\text { Total Completed Students }} \times 100 \%$}

Total number of students

With provisions if the percentage of classical completeness reaches $80 \%$, the class is considered complete. The data source in this study is a document recording the value of students by subject teachers and the results of teacher observation through observation sheets. The indicator of success for the class average is $\geq 77$. The indicator of success for classical completeness which refers to the completeness of individuals getting a score of $\geq 75 \%$ is $80 \%$. Indicators of success that are expected for the motivation of students who are expected to be at least $75 \%$ of students who are very well qualified.

\section{DISCUSSION}

This study emphasizes the increase of creativity in writing, so that there will be explanation about the development of student activities, creative student attitudes, creative group products and students' responses after learning. How to show the results and responses of students by using the Product Catalog. This is because the results of the innovation, super PC media and made creative learning during the implementation. The response of students can be more creative. 


\section{The Students' Creativity in Writing English in the First Cycle}

There are six categories of creativity which are used in the research. They are novelty, uniqueness (difference), authenticity (originality), solving (resolution), form (style) and variation (variation). These are used in the rubric of writing to measure students' creativity according to the criteria of creative products.

In apperception phase, the students are given some questions about supermarkets, student experiences, and items they normally buy/ the response is some students answer the teacher's questions but still look timid. In exploration activities, the teacher asks the students to sit in groups of 3 or 4 . The response is students move eagerly to find the group. They describe learning procedures and the objectives of the learning process and targets to be achieved. Teacher then shares media images of products that have been prepared before. Each group is given one picture, the creative response shows that students are very interested and curious of it. When the teacher asks students to discuss the image, students are sure to understand what the picture is. Students open and see pictures and then discuss immediately.

The teacher asks each student to write at least 10 words related to the image. Teacher gives examples of words relating to an object, such as the participation of the teacher showing a picture of baby milk products (baby milk) and the amount that says the word drink, healthy, box, white, powder, sweet, water, and so on. All students pay attention to the teacher happily because they do not want to lose to other groups. Teacher then asks students to return to discussion in their groups to determine the 10 selected words that will be submitted as a result of group discussions. Students discuss and give suggestions related to the words the group will choose.

In elaboration activities, the teacher asks students to make sentences from the words students have chosen with the aim of asking questions and providing information about various things. The creative response is students discuss with their groups. They share assignments in making sentences. The teacher explains the Simple Present format by giving an example sentence, for example the word box becomes "The milk is in the box". Creative response is students pay attention to the teacher while writing. When the teacher is accompanying students in their groups in the process of making sentences, 
they enthusiastically offer the results of their work to be corrected. Finally, there is a step to write a complete text.

There are two aspects in the research, student's creative respond to every activity in the learning process as data of process, and the creativity of writing descriptive text as data of result. There are two stages of observation, the observation on the learning process in the first cycle and in the second cycle. Students' creative respond and creative product of writing in the first cycle can be compared to the second cycle. First, the writer and the observer observe the students' creative respond by using teacher questionnaires in the early stages, which is learning on descriptive material. Then, after learning, the students are asked to fill out the questionnaire of creative respond. Next, the students are given a task of writing, the marks are added and averaged. There are six categories of creativity in writing. They are novelty, uniqueness (difference), authenticity (originality), solving (resolution), form (style) and variation. The result of cycle one can be observed in the table 1.

Table 1. Data of Process and Data of Outcomes in the First Cycle

\begin{tabular}{lll}
\hline No & Students' Data & \multicolumn{1}{c}{ Description } \\
\hline 1 & Data of Process: Students' & The score of creative response in writing process is \\
& creative response & 2.27 in the category "less creative" \\
\hline 2 & $\begin{array}{l}\text { Data of Result: students" } \\
\text { creativity in writing } \\
\text { descriptive text }\end{array}$ & $273 \%$ completed \\
& & \\
\end{tabular}

From the table, it can be observed that the students are less creative in responding learning activities in class, but $73 \%$ have already completed based on the Class Minimum Completeness score 77, because they still have problems, either to understand the teacher's instruction, subject matter or to present the description in a written text using appropriate vocabularies and sentences. Hence, the teacher tries to find the solution, students need more guidance and they are not accustomed to doing with this kind of activity. However, it has proved that the theory from Meier (2000:54) which states that teacher is the context maker and the students are the content makeris real in conducting an accelerated learning. 


\section{The Students' Creativity in Writing English in the Second Cycle}

In the second cycle, there is an improvement of method in teaching, the students are given a media together with the blank paper to be used as mind map. Then teacher conducts the lesson as prepared before. After developing ideas, they write sentences and develop it into a detailed text. The writing is corrected by the teacher. There is an explanation of the most common mistake in writing. The creative response is students pay attention, they want to get the best results for their group. Students return to discussion, some open a dictionary, some write sentences. They do self-edit. In the confirmation activity, the teacher gives opportunity to discuss with students (question and answer). The creative response is, some students ask and ask about several students who come in each group, some students try to ask.

Teacher gives questions to students who rectify misunderstandings, provide support and conclusions. The creative response: students are motivated to correct their problems by writing important things in their notebooks. In the closing activity, the teacher together with students make a summary / conclusion of the lesson. The creative response: studentseasily follow the teacher's direction with the help of the Product Catalog Supermarket. Then, to conduct reflection on activities that have been implemented and programmed. Students answer a number of teacher questions. They find it easier to write descriptive text in English through these activities. Feedback on the learning process and results. The creative response: the teacher corrects and improves student performance. The teacher gives an explanation of the purpose of the group and gives praise to active students and advice to students who are passive. Teacher then plans follow-up activities by providing good individual assignments.

Using the same points of students' creative respond observation and the six categories of creativity in writing: novelty, uniqueness (difference), authenticity (originality), solving (resolution), form (style) and variation, the result of cycle two can be observed in the table 2 . 
Table 2. Data of Process and Data of Result in the Second Cycle

\begin{tabular}{lll}
\hline No & Students' Data & \multicolumn{1}{c}{ Description } \\
\hline 1 & $\begin{array}{l}\text { Data of ProcessStudents" } \\
\text { creative response }\end{array}$ & $\begin{array}{l}\text { The score of motivation in learning is } 4.45 \text { in the } \\
\text { category “very creative" }\end{array}$ \\
\hline 2 & $\begin{array}{l}\text { Data of Result: students" } \\
\text { creativity in writing } \\
\text { descriptive text }\end{array}$ & $90,2 \%$ completed \\
\end{tabular}

Students' writing result now is improvingin variation according to the criteria of creative products. Student writing results have a novelty value from texts that are issued on the internet and books or other examples, because they have composed it with original words they discuss themselves. The writing results are also clearly unique about the objects they observed from the media. Having the value of the resolution or solution to the words they find, in the discussion, arrange the sentence and make it into the text. This requires a process of critical thinking. Creative form because it is diverse in providing information about objects.

Using the 4C learning process and Super PC media, students are not bored because they are invited to a creativity, make their own text. So naturally, the students try to understand the picture on catalogue, make use the vocabularies there and develop it into the text as a whole. Students' creativity in writing can improve beyond specified minimum completeness criteria. Uno and Koni (2013: 10) argue strongly that the maximum of the learning outcomes is due to the maximum learning-teaching process, and from this learning process it can be seen that this is suitable with what Suyatno (2009) states about the importance of media for students' learning which brings into an attractive, meaningful, and useful learning process.

\section{CONCLUSIONS AND SUGGESTIONS}

\section{Conclusions}

Creativity is a very urgent matter. It is important to improve creativity of our students so that as teachers, we can prepare Indonesian golden generation who will 
become leaders in the future. It can be developed by contextualizing learning with media that students have known everyday, supermarket product catalog.

The use of Super PC media in seventh grade of SMPN 2 Sidoarjo has a positive influence on improving student creativity. The use of Super PC can improve the creative character of students in Sidoarjo. This can be seen from class X at SMPN 2 Sidoarjo. The index is 2.27 with less creative category in the first cycle. Whereas in second cycle the index is 4.45 with very creative category using Super PC media. Students become excited and also in terms of practicality, clarity, quality and usefulness are very good and positive.

\section{Suggestions}

At the end of the study, based on the conclusions that have been taken, it is suggested to teachers should use learning technique to improve students' language competence. All students should be more enthusiastic in using speaking technique in English learning. For the next researchers should be able to look for other alternative to overcome the existing problem with the approaches, methods, technique, media or other strategies in order to provide new inputs for the next research.

\section{REFERENCES}

Ananda, Aris. (2014). Kreativitas Untuk Booming. Jakarta: Grasindo.

Asmani, Jamal Ma'mur. (2013). Internalisasi Pendidikan Karakter di Sekolah. Yogjakarta: Diva Press.

Aziz, Rahmat. (2009). "Karakteristik Pribadi Kreatif dan Kemampuan Menulis Kreatif” dalam Anime Indonesian Psychological Journal, Vol.24, No.2,116-123

Brookhart, Susan. (2010). How to Assess Higher Order Thinking Skill in your Classrooms. Alexandria: ASCD

Brown, H.D. (2001). Teaching by Principles: An Interactive Approach to Langauage Pedagogy. New York: Addison Weasley Longman,Inc.

Ferris, Dana. (2002). Teaching Students to Self-Edit in J.C. Richards \& W.A. Renandya (Ed). Methodology in Language Teaching (pp.328-335) Cambridge: Cambridge University Press. 
Hidayat, Ujang S \& Ramdhan, R.M. (2016). Pendidikan Karakter di Sekolah. Sukabumi: BM Publishing

King,FJ Ph.D, Ludwika G, M.S. \& Faranak Rohani, Ph.D. (2017). Higher Order Thinking Skills. Canberra: ESPedu.

Koshy, Valsa. (2005). Action Research forImproving Practice, A Practical Guide.

London: Paul Chapman Publishing.

Lickona, Thomas. (2015). Educating for Character Mendidik untuk Membentuk Karakter. Jakarta: Bumi Aksara.

Mangunwijaya,Y.B. (2003). Impian dari Yogyakarta: Kumpulan Esai Masalah Pendidikan. Jakarta: Kompas.

Meier, Dave. (2000). Accelerated Learning: Handbook. Cambridge: Cambridge. University Press.

Seow, Anthony. (2002). The Writing Process and Process Writing in J.C. Richards \& W.A. Renandya (Ed). Methodology in Language Teaching (pp.315-320) Cambridge: Cambridge University Press.

Sudjana,N., \& Rivai, A. (2015). Media Pengajaran. Bandung : SinarBaru Algensindo. Suyatno.(2009). Media Pembelajaran. Universitas Negeri Surabaya.

Uno, H.B., \& Koni, S. (2013). Asesment Pembelajaran. Jakarta: Bumiaksara. 